\title{
LIPID PEROXIDATION AND ANTIOXIDATIVE ENZYME ACTIVITY IN ERYTHROCYTES OF WORKERS OCCUPATIONALLY EXPOSED TO ALUIMINIUIM*
}

\author{
Petar BULAT ${ }^{1}$, Biljana POTKONJAK², and Ivana ĐUJIĆ ${ }^{3}$ \\ Institute of Occupational Health "Dr Dragomir Karajović" 1, Institute of Immunology "Torlak", \\ Institute of Chemistry, Technology and Metallurgy ${ }^{3}$, Beograd, Serbia \\ Received in September 2007 \\ Accepted in May 2008
}

\begin{abstract}
Current research indicates that lipid peroxidation could have a role in aluminium toxicity. The aim of this study was to asses lipid peroxidation and antioxidative enzyme activity in erythrocytes of workers occupationally exposed to aluminium. We investigated a group of 59 workers (Al group) exposed to aluminium fumes (contamination factor $\mathrm{F}=8.07$ to 13.47 , national maximal allowed concentration value is $2 \mathrm{mg} \mathrm{m}^{-3}$ ). The control group (C group) consisted of 75 subjects employed in lime production who had not been occupationally exposed to aluminium or any known toxic substance.

Erythrocyte aluminium concentrations were significantly higher in the exposed group than controls [Al group $(8.41 \pm 3.66) \mu \mathrm{g} \mathrm{L}^{-1}, \mathrm{C}$ group $\left.(5.60 \pm 0.86) \mu \mathrm{g} \mathrm{L}^{-1}, \mathrm{p}<0.001\right]$. In the Al group, erythrocyte malondialdehyde concentration was also significantly higher [Al group (189.59 \pm 81.27$) \mu \mathrm{mol} \mathrm{L}^{-1}, \mathrm{C}$ group $\left.(105.21 \pm 49.62) \mu \mathrm{mol} \mathrm{L}^{-1}, \mathrm{p}<0.001\right]$ and antioxidative enzyme activity reduced for glucoso-6-phosphatedehydrogenase [Al group (5.05 \pm 1.70$) \mathrm{IU} \mathrm{g}^{-1} \mathrm{Hb}, \mathrm{C}$ group (12.53 \pm 4.12$) \mathrm{IU} \mathrm{g} \mathrm{g}^{-1} \mathrm{Hb}, \mathrm{p}<0.001$ ], glutathione reductase [Al group $(1.41 \pm 0.56) \mathrm{IU} \mathrm{g}^{-1} \mathrm{Hb}, \mathrm{C}$ group $(1.89 \pm 0.57) \mathrm{IU} \mathrm{g}^{-1} \mathrm{Hb}, \mathrm{p}<0.001$ ], glutathione peroxidase [Al group (12.37 \pm 5.76$) \mathrm{IU} \mathrm{g}^{-1} \mathrm{Hb}, \mathrm{C}$ group $(15.54 \pm 4.85) \mathrm{IU} \mathrm{g} \mathrm{g}^{-1} \mathrm{Hb}, \mathrm{p}<0.001$ ], catalase [Al group (116.76 \pm 26.60$) \mathrm{IU} \mathrm{g} \mathrm{g}^{-1} \mathrm{Hb}$, C group $\left.(158.81 \pm 71.85) \mathrm{IU} \mathrm{g}^{-1} \mathrm{Hb}, \mathrm{p}<0.001\right]$ and superoxide dismutase [Al group (1175.8 \pm 149.9$) \mathrm{IU} \mathrm{mg}^{-1} \mathrm{Hb}, \mathrm{C}$ group $\left.(1377.9 \pm 207.5) \mathrm{IU} \mathrm{mg}^{-1} \mathrm{Hb}, \mathrm{p}<0.001\right]$.
\end{abstract}

KEY WORDS: catalase, glucoso-6-phosphate-dehydrogenase, glutathione peroxidase, glutathione reductase, malondialdehyde, occupational exposure, superoxide dismutase

The first data on aluminium adverse health effects originate from 1947 when Shaver and Ridell described 23 cases of pulmonary diseases in 344 workers processing bauxite (Shaver's disease) (1). Current research has been directed towards studying the association between aluminium exposure and changes in the central nervous system (especially Alzheimer's disease), changes in the bones, and microcyte hypochromic anaemia. Recent research (2) shows that aluminium may induce changes in

\footnotetext{
This paper has partly been presented at the International Symposium Safety and Health at Work in Metal Industry: 2007 - Focus on Aluminium Industry" held in Šibenik, Croatia on 24-26 May 2007.
}

the activity of a number of antioxidative enzymes (xanthine oxidase, glutathione peroxidase, superoxide dismutase), but so far no acceptable explanations have been proposed of the mechanisms through which it disturbs normal enzyme activity. In heavy metal exposure this can be explained by their affinity for sulfhydryl groups. However, this mechanism does not apply to exposure to aluminium and other trivalent cations, since this cation group does not show affinity for sulfhydryl groups (3). Recent data indicate that decreased erythrocyte delta-aminolevulinate dehydratase activity in haemodialysed patients with increased aluminium levels is related to the oxidation of sulfhydryl groups (4). The last few decades have 
seen increasing evidence that oxidative stress has an important role in aluminium toxicity (5-14). Therefore, the aim of this study was to examine lipid peroxidation and the activity of antioxidative enzymes in erythrocytes of workers occupationally exposed to aluminium.

\section{SUBJECTS AND METHODS}

The study included a group of 59 workers (Aluminium group) occupationally exposed to aluminium in aluminium casting and electrolysis. Their mean age was $(43.5 \pm 6.2)$ years and the average duration of aluminium exposure $(16.8 \pm 4.9)$ years. The results of ambient monitoring indicate that this group was dominantly exposed to aluminium fumes [contamination factor ${ }^{1}$ ranged within $\mathrm{F}=8.07$ to 13.47, national maximal allowed concentration (MAC) is $2 \mathrm{mg} \mathrm{m}^{-3}$.

We also found increased levels of $\mathrm{SO}_{2}$, fluoride and $\mathrm{CO}\left(\mathrm{SO}_{2}\right.$ contamination factor $\mathrm{F}=3.15$, national $\mathrm{MAC}=$ $5 \mathrm{mg} \mathrm{m}^{-3}$; fluoride contamination factor $\mathrm{F}=1.29$, national $\mathrm{MAC}=2.5 \mathrm{mg} \mathrm{m}^{-3}$, and $\mathrm{CO}$ contamination factor $F=1.02$, national $M A C=58 \mathrm{mg} \mathrm{m}^{-3}$ ).

The control group consisted of 75 workers from the same company employed in lime production about $20 \mathrm{~km}$ away from the aluminium production plant who had never been occupationally exposed to aluminium or any other known toxic substance. The mean age of controls was $(44.7 \pm 7.4)$ years.

Erythrocyte aluminium concentrations were determined using flameless atomic absorption (15) spectrophotometer "Perkin Elmer" model 910. Erythrocyte selenium was determined using hydride generation atomic absorption spectrometry (16).

Hematocrit, erythrocyte count and haemoglobin were determined using a Helige haematoscope.

Erythrocyte malondialdehyde (MDA) concentrations were determined by UV-spectrophotometry (17) and so were the activities of antioxidative enzymes: glucose-6-phosphate dehydrogenase (G6PDH) (18), glutathione reductase (GR), superoxide dismutase (SOD) (19), glutathione peroxidase (GPx) (20), and catalase (21). All the analyses were performed on a UV-spectrophotometer Gilford model 250.

The data were analysed using the statistic package SPSS for Windows version 6.1. Probability distribution

Contamination factor $=$ actual $\mathrm{Al}$ concentration/national maximal allowed concentration was tested using the Kolmogorov Smirnov test. The data were analysed using Student's $t$-test for two independent samples and linear correlation. Data are presented as means, standard deviations, and $95 \%$ confidence intervals $(\mathrm{CI})$. Values were considered significantly different if the $p$ value was less than 0.05 $(\mathrm{p}<0.05)$.

\section{RESULTS}

Erythrocyte aluminium levels in the exposed group were significantly higher than in the control group $(p<0.001)$. Erythrocyte selenium concentration in both groups was similar, but slightly higher in the Al group (Table 1).

Haematological parameters were within normal ranges in both groups. Haemoglobin levels were somewhat higher in the Al group, but the difference was not significant. Erythrocyte count was also higher in the $\mathrm{Al}$ group. A somewhat higher haematocrit was found in the Al group, but again the difference was not significant (see Table 1 for all three parameters).

Lipid peroxidation in erythrocytes was assessed by measuring MDA levels in erythrocytes. They were significantly higher in the Al group than in controls $(\mathrm{p}<0.001)$ (Table 1).

Erythrocyte G6PDH, GR, GPx, catalase, and SOD activities in the $\mathrm{Al}$ group were significantly lower than in controls $(p<0.001)$ (Table 1).

In the $\mathrm{Al}$ group a negative correlation was found between erythrocyte MDA levels and GPx activity $(r=0.537)(p<0.001)$.

\section{DISCUSSION}

Previous research has indicated that oxidative stress has an important role in aluminium toxicity (5-14). In accordance with this is the hypothesis by Joshi (5) that aluminium interferes with iron ions, particularly with trivalent iron ions which participate in oxidoreduction. This results in increased production of free radicals. Kong et al. (7) proposed that aluminium builds a complex with $\mathrm{O}_{2}$. In literature there are a number of studies proving that oxidative stress is responsible for aluminium effects on brain cells (8-11), as well as other tissues (12-14, 22, 23).

Our results are in line with a similar study by Guo et al. (23) in which serum MDA levels were significantly 
Table 1 Erythrocyte aluminium, selenium, malondialdehyde, and haemoglobin levels, haematocrit, erythrocyte count, G6PDH, GR, GPx, catalase, and SOD activity in erythrocytes of exposed Al workers and controls

\begin{tabular}{|c|c|c|c|c|}
\hline & \multicolumn{2}{|c|}{ Exposed $(n=59)$} & \multicolumn{2}{|c|}{ Control $(n=75)$} \\
\hline & mean $\pm \mathrm{SD}$ & $\mathrm{CI}^{+}$ & mean $\pm S D$ & $\mathrm{CI}^{+}$ \\
\hline Al in erythrocytes / $\mu \mathrm{g} \mathrm{L}^{-1}$ & $8.41 \pm 3.66 * * *$ & $7.24-9.59$ & $5.60 \pm 0.86$ & $5.32-5.87$ \\
\hline Se in erythrocytes $/ \mu \mathrm{g} \mathrm{L}^{-1}$ & $65.80 \pm 10.57$ & $62.42-69.18$ & $62.77 \pm 11.71$ & $59.03-66.52$ \\
\hline Hematocrit / L L-1 & $0.447 \pm 0.045$ & $0.434-0.459$ & $0.433 \pm 0.026$ & $0.427-0.439$ \\
\hline Hemoglobin / g L-1 & $151.6 \pm 11.6$ & $148.4-154.7$ & $149.5 \pm 9.7$ & $147.2-151.8$ \\
\hline Erythrocyte count / x10 $0^{12} \mathrm{~L}^{-1}$ & $4.51 \pm 0.46$ & $4.38-4.63$ & $4.46 \pm 0.22$ & $4.41-4.51$ \\
\hline MDA in erythrocytes / $\mu \mathrm{mol} \mathrm{L}-1$ & $189.59 \pm 81.27 * * *$ & $161.68-217.51$ & $105.21 \pm 49.62$ & $93.63-116.79$ \\
\hline G6PDH / IU g $g^{-1} \mathrm{Hb}$ & $5.05 \pm 1.70 * * *$ & 4.60-5.49 & $12.53 \pm 4.12$ & $11.58-13.48$ \\
\hline $\mathrm{GR} / \mathrm{I} U \mathrm{~g}^{-1} \mathrm{Hb}$ & $1.41 \pm 0.56 * * *$ & $1.27-1.56$ & $1.89 \pm 0.57$ & $1.76-2.03$ \\
\hline $\mathrm{GPx} / \mathrm{I} U \mathrm{~g}^{-1} \mathrm{Hb}$ & $12.37 \pm 5.76 * * *$ & $10.86-13.87$ & $15.54 \pm 4.85$ & $14.41-16.67$ \\
\hline Catalase / IU g g $\mathrm{Hb}$ & $116.76 \pm 26.60 * * *$ & 109.77-123.76 & $158.81 \pm 71.95$ & $142.26-175.37$ \\
\hline $\mathrm{SOD} / \mathrm{IU} \mathrm{mg}^{-1} \mathrm{Hb}$ & $1175.8 \pm 149.9 * * *$ & 1136.1-1215.6 & $1377.9 \pm 207.5$ & $1330.2-1425.7$ \\
\hline
\end{tabular}

$\mathrm{Cl}^{+}-95 \%$ Confidence interval

*** Exposed us. control group $p<0.001$.

higher in subjects occupationally exposed to aluminium than in controls. Both studies have shown increased lipid peroxidation in workers occupationally exposed to aluminium.

Several studies have reported decreased GR activity in rats exposed to aluminium (24-26). In our study, decreased GR activity was also found in the Al group. The mechanism of GR inhibition is still not fully understood. It may be the result of decreased G6PDH activity, which was also found in the exposed workers. Since GR activity directly depends on reduced nicotinamide adenine dinucleotide phosphate (NADP) levels in erythrocytes, and having in mind that glycolysis via hexozomonophosphate shunt is the only source of reduced NADP in erythrocytes, lower GR activity is probably the result of the lower activity of G6PDH, an enzyme regulating the glycolytic pathway. Lower G6PDH activity in the Al group may be explained by experimental studies indicating that aluminium causes G6PDH inhibition. According to Cho and Joshi (27), aluminium binding to the molecule of G6PDH inhibits its activity. Zaman et al. $(24,25)$ also suggest that exposure to aluminium leads to lower G6PDH activity in rat erythrocytes. The mechanism of aluminium action has not yet been entirely elucidated. Based on the results by $\mathrm{Cho}$ and Joshi (27) it may be assumed that in erythrocytes aluminium ions bind to G6PDH and reduce its activity. However, the site where aluminium binds to G6PDH has not yet been found.
Rosemeyer et al. (28) proved that in erythrocyte cytosol GR, G6PDH, and 6-phospho-gluconatedehydrogenase form a complex in a 1:1:10 ratio, respectively. Having in mind the G6PDH inhibition hypothesis and data from Rosemeyer et al. (28), we can assume that aluminium ions bind to this complex and change its quaternary structure, which then affects enzyme activity in that complex.

In our study the Al group showed a significantly lower erythrocyte activity of glutathione peroxidase. This is in accordance with Guo et al. (23) who found lower serum GPx activities in a group of 59 workers employed in aluminium electrolysis. Animal study data also suggest that exposure to aluminium decreases GPx activity in rat erythrocytes (2) and brain (29). The results of these studies are comparable with the results of similar studies in which increased lipid peroxidation was found. Studies of subjects with increased lipid peroxidation found both increased (30) and reduced GPx activity $(31,32)$. Meng (31) has shown that during intensive lipid peroxidation, a short term initial increase in GPx activity occurs, followed by a drop which is maintained throughout exposure. This might also be the case in our study and Guo et al. (23). This hypothesis is further supported by the negative correlation between erythrocyte GPx activity and MDA levels found in study and Guo et al. (24). There is an opposite hypothesis that a decrease in GPx activity leads to intensified lipid peroxidation and higher erythrocyte MDA level. However, as erythrocytes 
have other antioxidative defence mechanisms beside $\mathrm{GPx}$, this hypothesis is not sound.

The activity of GPx is greatly influenced by erythrocyte selenium levels. Since selenium levels in our study were comparable in both groups (being negligibly higher in the Al group) and since the subjects originated from the same population with similar life habits, it is possible to exclude the influence of selenium deficiency as a cause of lower erythrocyte GPX activity. This however does not entirely exclude an interaction between aluminium and selenium, but the probability of that interaction is small.

There are no literature data on erythrocyte catalase activity in occupational exposure to aluminium. Our results indicate that erythrocyte catalase activity is significantly lower in the aluminium-exposed group, but the mechanism of catalase inhibition is not clear. Having in mind the role of catalase in erythrocyte antioxidative defense system and the fact that lipid peroxidation was higher in our and Guo et al. (23) studies, it could be expected that catalase activity is increased. Mena et al. (33) had a similar paradoxical finding of reduced catalase activity in subjects with increased amounts of free radicals during an intensive physical strain. It is possible that aluminium inhibits catalase activity through an unknown direct or indirect mechanism. This inhibition could be a consequence of the oxidation of catalase sulfhydryl groups, as is the case with decreased erythrocyte delta-aminolevulinate dehydratase activity in haemodialysed patients (4).

Data on SOD activity and aluminium exposure are controversial. Shainkin Kestenbaum et al. (34) and Hasanoglu et al. (35) reported significantly decreased SOD activity in erythrocytes of haemodialysed patients. Likewise, Abd-Elghaffar et al. (36) reported decreased brain SOD activity in rabbits exposed to aluminium chloride. In contrast, an in vitro study (37) reports unaltered SOD activity. The results of our study show a significant decrease in erythrocyte SOD activity in workers occupationally exposed to aluminium. Surprisingly enough, Guo et al. (23) got quite the opposite result in a similar group, that is, an increased whole blood SOD activity. They explained it as a kind of compensatory reaction. Perhaps the difference between the two studies is because we measured SOD activity in erythrocytes and Guo et al. (23) in whole blood. A recent study by Di et al. (38) suggests that lower SOD activity may have something to do with the altered conformation of SOD molecule due to formation of Al-SOD complex, but this does not shed any more light on the difference between our study and Guo et al. (23).
However, decreased activities of all studied antioxidative enzymes in erythrocytes of workers occupationally exposed to aluminium raise at least two questions: what is their cause and what can be the consequences. There are two possible explanations of the cause: direct or indirect aluminium action inhibiting enzyme activity or some kind of a exhausting mechanism. According to the latter hypothesis, based on similar findings by Meng et al. (31), long-term exposure to oxidative stress leads to exhaustion of antioxidative enzymes.

The consequences of decreased antioxidative enzyme activity remain unknown. No anaemia was found in the Al group anaemia. Erythrocyte count in both groups was within the normal range, and it was even a little higher in the Al group than in controls. Haemoglobin levels were also within the normal range in both groups (somewhat higher in the $\mathrm{Al}$ group). However, as the antioxidative enzyme activity in erythrocytes is decreased, some consequences like oxidative stress and anaemia might be expected with intake of exogenous oxidants such as food and drugs.

Our results indicate a need for further research on lipid peroxidation in erythrocytes of workers occupationally exposed to aluminium. Further studies focused on G6PDH deficient workers and workers with selenium deficiency might produce further knowledge on lipid peroxidation and antioxidative enzyme activity in erythrocytes of workers occupationally exposed to aluminium.

\section{REFERENCES}

1. Shaver CG, Riddell AR. Lung changes associated with manufacture of alumina abrasives. J Ind Hyg Toxicol 1947;29:145-57.

2. Moumen R, Oukhatara NA, Bureau F, Fleury C, Bougle D, Arhan P, Neuville D, Viader F. Alumininium increases xanthine oxidase activity and disturbs antioxidant status in the rat. J Trace Elem Med Biol 2001;15:89-93.

3. De Verneuil H, Sassa S, Kappas A. Purification and properties of uroporfirinogen decarboxylase from human erythrocytes. J Biol Chem 1983;258:245460.

4. Valentini J, Schmitt GC, Grotto D, Santa Maria LD, Boeira SP, Piva SJ, Brucker N, Bohrer D, Pomblum VJ, Emanuelli T, Garcia SC. Human erythrocyte delta-aminolevulinate dehydratase activity and oxidative stress in hemodialysis patients. Clin Biochem 2007;40:591-4. 
5. Joshi JG. Aluminum, a neurotoxin which affects diverse metabolic reactions. Biofactors 1990;2:163-9.

6. Joshi JG. Neurochemical hypothesis: participation by aluminum in producing critical mass of colocalized errors in brain leads to neurological disease. Comp Biochem Physiol 1991;100:103-5.

7. Kong S, Liochev S, Fridovich I. Aluminum (III) facilitates the oxidation of NADH by the superoxide anion. Free Radic Biol Med 1992;13:79-81.

8. Lal B, Gupta A, Murthy RC, Ali MM, Chandra SV. Aluminum ingestion alters behaviour and some neurochemicals in rats. Indian J Exp Biol 1993;31:30-5.

9. Bondy SC, Ali SF, Guo-Ross S. Aluminum but not iron treatment induces pro-oxidant events in the rat brain. Mol Chem Neuropathol 1998;34:219-32.

10. Campbell A, Prasad KN, Bondy SC. 1999. Aluminuminduced oxidative events in cell lines: glioma are more responsive than neuroblastoma. Free Radic Biol Med 1999;26:1166-71.

11. Oshiro S, Kawahara M, Kuroda Y, Zhang C, Cai Y. Kitajima S, Shirao M. Glial cells contribute more to iron and aluminum accumulation but are more resistant to oxidative stress than neuronal cells. Biochim Biophys Acta 2000;1502(3):405-14.

12. Anane R, Creppy EE. Lipid peroxidation as pathway of aluminium cytotoxicity in human skin fibroblast cultures: prevention by superoxide dismutase + catalase and vitamins E and C. Hum Exp Toxicol 2001;20:477-81.

13. Sargazi M, Shenkin A, Roberts NB. Aluminium-induced injury to kidney proximal tubular cells: Effects on markers of oxidative damage. J Trace Elem Med Biol 2006;19:267-73.

14. Kaneko N, Sugioka T, Sakurai H. Aluminum compounds enhance lipid peroxidation in liposomes: insight into cellular damage caused by oxidative stress. J Inorg Biochem 2007;101:967-75.

15. LeGendre GR, Alfrey AC. Measuring picogram amounts of aluminum in biological tissue by flameless atomic absorption analysis of a chelate. Clin Chem 1976;22:53-6.

16. Hansson L, Pettersson J, Eriksson L, Olin A. Atomic absorption spectrometric determination of selenium in human blood components. Clin Chem 1989;35:53740.

17. Zdenek A, Placer A, Linda L, Cushma N, Connor Johnson B. Estimation of product of lipid peroxidation (malonyl dialdehyde) in biochemical systems. Anal Biochem 1966;16:359-64.

18. Kornberg A, Horecker BL. Glucose-6-phosphate dehydrogenase. In: Colowick SP, Kaplan NO, editors. Methods in enzymology. New York: Academic Press; 1955. p. 323-35.

19. Misra HP, Fridovich I. The role of superoxide anion in the autoxidation of epinephrine and a simple assay for superoxide dismutase. J Biol Chem 1972;247:3170-5.
20. Paglia DE, Valentine WN. Studies on the quantitive and qualitative characterisation of glutathione peroxidase. J Lab Clin Med 1967;70:158-63.

21. Bonnlohsen KR. Blood catalase. In: Colowick SP, Kaplan NO, editors. Methods in enzymology. New York: Academic Press; 1955. p. 781-4.

22. Potkonjak D, Đujić I, Bulat P. Profesionalna ekspozicija aluminijumu i peroksidacija lipida. [Occupational exposure to aluminum and lipid peroxidation, in Serbian]. Revija rada specijalno izdanje 1992;263:1011.

23. Guo Z, Zhu Q, Hu C, Yang Y. [Study on lipid peroxidation of electrolyzing-aluminum workers, in Chinese]. Wei Sheng Yan Jiu 2002;31:78-80.

24. Zaman K, Miszta H, Dabrowski Z. The effect of aluminium upon the activity of selected bone marrow enzymes in rats. Folia Haematol (Leipz) 1990;117:44751.

25. Zaman K, Zaman W, Siddique H. Hematological and enzymatic results of aluminum intoxication in rats. Comp Biochem Physiol C 1993;105:73-6.

26. Sharma P, Ahmad Shah Z, Kumar A, Islam F, Mishra KP. Role of combined administration of Tiron and glutathione against aluminum-induced oxidative stress in rat brain. J Trace Elem Med Biol 2007;21:63-70.

27. Cho SW, Joshi JG. Time-dependent inactivation of glucose-6-phosphate dehydrogenase from yeast by aluminum. Toxicol Lett 1989;47:215-9.

28. Rosemeyer MA, Cohen P, Pearse BMF, Worthington DJ. Comparison between physical properties of glutathione reductase and NADP-linked dehydrogenases. In: Singer TP, Ondarza RN, editors. Mechanisms of oxidizing enzymes. Amsterdam: Elsevier North Holland; 1978. p. 23-8.

29. Sharma P, Mishra KP. Aluminum-induced maternal and developmental toxicity and oxidative stress in rat brain: response to combined administration of Tiron and glutathione. Reprod Toxicol 2006;21:313-21.

30. Hart BA, Voss GW, Shatos MA, Doherty J. Crosstolerance to hyperoxia following cadmium aerosol pretreatment. Toxicol Appl Pharmacol 1990;103:25570.

31. Meng XM. [Mechanism of damage to erythrocytes after burn injury in rat-changes in lipid peroxidation, antioxidant function and sulfhydryl groups, in Chinese]. Chung Hua Cheng Hsing Shao Shang Wai Ko Tsa Chih 1991;7:205-7.

32. Turan B, Delilbasi E, Dalay N, Sert S, Afrasyap L, Sayal A. Serum selenium and glutathione-peroxidase activities and their interaction with toxic metals in dialysis and renal transplantation patients. Biol Trace Elem Res 1992;33:95-102.

33. Mena P, Maynar M, Gutierrez JM, Maynar J, Timon J, Campillo JE. Erythrocyte free radical scavenger enzymes in bicycle professional racers. Adaptation to training. Int J Sports Med 1991;12:563-6. 
34. Shainkin Kestenbaum R, Caruso C, Berlyne GM. Reduced superoxide dismutase activity in erythrocytes of dialysis patients: a possible factor in the etiology of uremic anemia. Nephron 1990;55:251-3.

35. Hasanoglu E, Altan N, Sindel S, Ongun CO, Bali M, Altintaş E. The relationship between erythrocyte superoxide dismutase activity and plasma levels of some trace elements (Al, Cu, Zn) of dialysis patients. Gen Pharmacol 1994;25:107-10.

36. Abd-Elghaffar SKh, El-Sokkary GH, Sharkawy AA. Aluminum-induced neurotoxicity and oxidative damage in rabbits: protective effect of melatonin. Neuro Endocrinol Lett 2005;26:609-16.

37. Serra MA, Barassi V, Canavese C, Sabbioni E. Aluminum effect on the activity of superoxide dismutase and of other antioxygenic enzymes in vitro. Biol Trace Elem Res 1991;31:79-96.

38. Di J, Yao K, Han W, Bi S. Study on the interaction of copper-zinc superoxide dismutase with aluminum ions by electrochemical and fluorescent method. Spectrochim Acta A Mol Biomol Spectrosc 2006;65:896-900. 


\section{Sažetak}

\section{LIPIDNA PEROKSIDACIJA I AKTIVNOST ANTIOKSIDATIVNIH ENZIMA U ERITROCITIMA RADNIKA PROFESIONALNO IZLOŽENIH ALUMINIJU}

Rezultati suvremenih istraživanja pokazuju da lipidna peroksidacija može imati važnu ulogu u toksičnosti aluminija. Cilj istraživanja bio je da se ispita lipidna peroksidacija i aktivnost antioksidativnih enzima u eritrocitima kod radnika profesionalno izloženih aluminiju. Ispitivanjem je obuhvaćena skupina od 59 radnika (Al skupina) profesionalno izloženih aluminiju (faktor onečišćenja $F=8,07$ do 13,47 , nacionalna maksimalno dopuštena koncentracija je $2 \mathrm{mg} \mathrm{m}^{-3}$ ). Kontrolna skupina sastojala se od 75 osoba zaposlenih u proizvodnji vapna koje nikada nisu bile profesionalno izložene aluminiju ni drugim toksičnim tvarima. U skupini izloženoj aluminiju utvrđene su statistički signifikantno više koncentracije aluminija u eritrocitima nego u kontrolnoj skupini [Al skupina $(8,41 \pm 3,66) \mu \mathrm{g} \mathrm{L}^{-1}$, kontrolna skupina $\left.(5,60 \pm 0,86) \mu \mathrm{g} \mathrm{L}^{-1}, \mathrm{p}<0,001\right]$. U Al skupini utvrđene su statistički značajno više koncentracije malondialdehida u eritrocitima [Al skupina $(189,59 \pm 81,27) \mu \mathrm{mol} \mathrm{L}^{-1}$, kontrolna skupina $\left.(105,21 \pm 49,62) \mu \mathrm{mol} \mathrm{L}^{-1}, \mathrm{p}<0,001\right]$. Također, u Al skupini utvrđene su i statistički značajno niže aktivnosti antioksidativnih enzima u eritrocitima: glukozo6-fosfatdehidrogenaza [Al skupina $(5,05 \pm 1,70) \mathrm{IU} \mathrm{g}^{-1} \mathrm{Hb}$, kontrolna skupina $(12,53 \pm 4,12) \mathrm{I} U \mathrm{~g}^{-1} \mathrm{Hb}$, $\mathrm{p}<0,001$ ], glutationreduktaza [Al skupina $(1,41 \pm 0,56) \mathrm{IU} \mathrm{g}^{-1} \mathrm{Hb}$, kontrolna skupina $(1,89 \pm 0,57) \mathrm{IU} \mathrm{g}^{-1} \mathrm{Hb}$, $\mathrm{p}<0,001$ ], glutationperoksidaza [Al skupina $(12,37 \pm 5,76) \mathrm{IU} \mathrm{g}^{-1} \mathrm{Hb}$, kontrolna skupina $(15,54 \pm 4,85) \mathrm{IU}$ $\mathrm{g}^{-1} \mathrm{Hb}, \mathrm{p}<0,001$ ], katalaza [Al skupina $(116,76 \pm 26,60) \mathrm{IU} \mathrm{g} \mathrm{g}^{-1} \mathrm{Hb}$, kontrolna skupina $(158,81 \pm 71,85) \mathrm{IU}$ $\left.\mathrm{g}^{-1} \mathrm{Hb}, \mathrm{p}<0,001\right]$ i superoksiddizmutaza [Al skupina $(1175,8 \pm 149,9) \mathrm{IU} \mathrm{mg}^{-1} \mathrm{Hb}$, kontrolna skupina $\left.(1377,9 \pm 207,5) \mathrm{IU}_{\mathrm{mg}}{ }^{-1} \mathrm{Hb}, \mathrm{p}<0,001\right]$.

KLJUČNE RIJEČI: glukozo-6-fosfatdehidrogenaza, glutationperoksidaza, glutationreduktaza, katalaza, malondialdehid, profesionalna izloženost, superoksiddismutaza

\section{CORRESPONDING AUTHOR:}

Professor Petar Bulat, MD, PhD

Institute of Occupational Health "Dr Dragomir Karajović"

Deligradska 29, 11000 Beograd, Serbia

E-mail: bulatp@EUnet.rs 